Volume 10, Issue 4, July-August 2019, pp.196-204, Article ID: IJM_10_04_019

Available online at http://iaeme.com/Home/issue/IJM?Volume $=10 \& \overline{\text { Issue }}=4$

Journal Impact Factor (2019): 9.6780 (Calculated by GISI) www.jifactor.com ISSN Print: 0976-6502 and ISSN Online: 0976-6510

\title{
MODEL DEVELOPMENT FOR EMPLOYEE RETENTION IN INDIAN CONSTRUCTION INDUSTRY USING STRUCTURAL EQUATION MODELING (SEM)
}

\author{
*Dr. Arunangshu Giri \\ Associate Professor, School of Management \& Social Science, \\ Haldia Institute of Technology, Haldia, West Bengal, India. \\ Dr. Sourav Gangopadhyay \\ Assistant Professor, Management Department, \\ Haldia Institute of Management, Haldia, West Bengal, India. \\ Jayeeta Majumder \\ Assistant Professor, Management Department, \\ Haldia Institute of Management, Haldia, West Bengal, India.

\section{Dr. Pradip Paul} \\ Senior Manager (Retail Sales), Haldia Divisional Office, \\ Indian Oil Corporation Ltd., Haldia, West Bengal, India \\ *(Corresponding Author)
}

\begin{abstract}
In India, number of construction companies is increasing day by day so the demand for the efficient employees is also increasing, but there are lots of dissatisfaction is observed among the employees of construction companies in India which causes increasing rate of employee attrition.

Employees of construction industry can be satisfied by motivating them with financial and non-financial encouragements. In this paper, factors affecting employee retention in the construction industry were identified and assessed. The views of 287 employees were collected by the help of structure questionnaires distributed to Architects, Civil Engineers, Builders, Surveyors, Clarks and others from selected construction companies in India. Basic facilities, working environment, scope \& opportunities and employee satisfaction were found as the major factors affecting employee retention. To analyze the impact of those factors on the employee retentions, Structural Equation Modeling (SEM) through AMOS Software has been used here. The study shows that all identified factors have significant relationship with the employee retention.
\end{abstract}


Keywords: Employee Retention; Employee Attrition; Indian Construction Industry, Structural Equation Modelling.

Cite this Article: Dr. Arunangshu Giri, Dr. Sourav Gangopadhyay, Jayeeta Majumder and Dr. Pradip Paul, Model Development for Employee Retention in Indian Construction Industry using Structural Equation Modeling (Sem), International Journal of Management, 10 (4), 2019, pp. 196 - 204.

http://iaeme.com/Home/issue/IJM?Volume $=10 \&$ Issue $=4$

\section{INTRODUCTION}

Activities of construction companies are increasing gradually because of industrialization and urbanization due to increasing population and changing lifestyle. The construction industry depends on huge number of employees for executing all activities because these activities cannot be fully carried out through automation. Therefore employee retention is important for this industry (Ojelabi et al., 2018). Employees are satisfied if their needs (basic facilities and nonfinancial incentives) are fulfilled properly in the organization. Thus employees retain despite the attraction of a good offers from other organization (Ngonde, 2015). Employee satisfaction upholds loyalty and commitment towards the organization. It has a positive relationship with employee retention (Danso, 2012). The attrition of the employee in construction companies depends on several factors including interpersonal relationship, competitive salary, challenging work, job security, work autonomy, workload and flexibility.

\section{REVIEW OF LITERATURE}

Basic facility is one of the most important factors for employee retention. It focuses on the variables like salary, job security, etc. that influence employee satisfaction (Amin et al., 2015). These variables are related with financial and non-financial incentives that influence employee retention. The job security is also important factor of retention as secured employee is having high satisfaction towards organization which leads to develop low attrition. The infrastructure is playing always a positive role in the process of retention of the employee (Blair \& Jordan, 1994 \& Mubatsi, 2012). Adequate infrastructure is required always (Anifowose \& Lawal, 2013). An improper infrastructure facility is creating unnecessary stress especially in case of rush hour which ultimately effects on the job satisfaction. According to a study, $64 \%$ of employees are satisfied due to infrastructure. Properly managed infrastructure is able to flourish the business (IFMA, 2001). The working environment in the construction companies has direct influence on the performance of the employees. Stressful working condition is lowering the performance of the employees (George \& Jones, 1999). Good working environment enhances the level of satisfaction of the employees (Kasule, 2015). The positive working environment produces the sense of belongingness among the employee (Miller, et al., 2001). The working environment has the direct influence on the attritions ( $\mathrm{Ng}^{\prime}$ ethe, et. al., 2012). Working environment is depending on some variables like communication, workload distribution, leadership quality, motivation from colleagues etc. and promotes intense employee engagement in the organization. Many employees are dissatisfied due to excessive work pressure (Zainudin, et. al., 2010). Stressful working condition also hampers the work life balance. The relationship among the employees is also an important aspect of the working environment. The attrition is directly and highly correlated with the relation among the employees. The leadership quality is playing a pivotal role in the employee attrition. Proper supervision or the good leadership quality is able to reduce the stress of the employee and earn the commitment from them (Landsman, 2008 \& Heish, 2012). Scopes and opportunities is one of the important factors because every employee wants that organization where ample of opportunities of career improvements exist. Provision for the development and the training in the organization is able 
to create a positive mentality among the employee that the employer is caring about their development which ultimately draws attraction towards the organization (Huselid, 1995 \& Dockel, 2003), because the talented or the skilled workers have ample of job opportunities and it is the organization who is supposed to attract and retain them. Autonomy is an important issue as it provides opportunity to take decision regarding work by the employee (Metcalf, et al., 2005 \& Strauss, 2006) and the employee participation has direct influence on the employee retention (Bhatti, et al., 2011). Recognition and the opportunity for the promotion are other good characteristics of organization that are looking for the improvement of the employee. Reward system is a kind of promotional activities and it is a positive step as it recognizes the employee's performance.

\section{HYPOTHESES DEVELOPMENT}

H1: 'Basic Facilities' positively influences 'Employee Satisfaction' in Construction Industry.

H2: 'Working Environment' positively influences 'Employee Satisfaction' in Construction Industry.

H3: 'Scope \& Opportunity' positively influences 'Employee Satisfaction' in Construction Industry.

H4: 'Employee Satisfaction' positively influences 'Employee Retention' in Construction Industry.

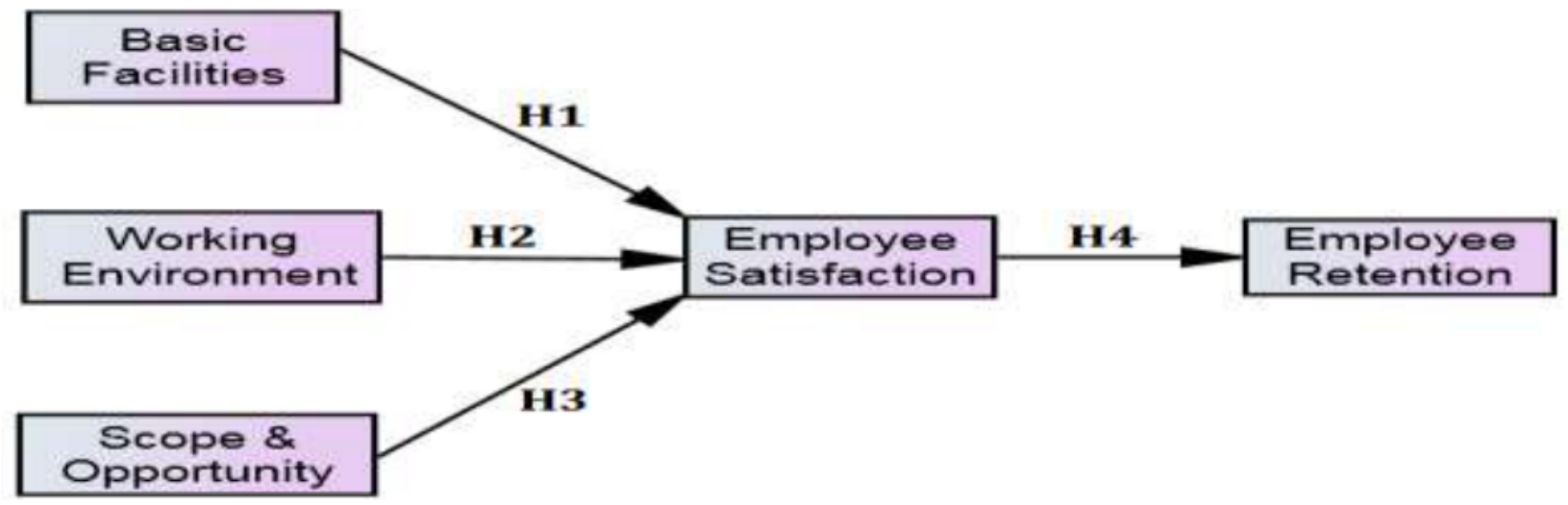

Figure 1 Hypothesized Research Model Establishment

\section{RESEARCH METHODOLOGY}

In this study, research model (Figure 1) has been established by the help of primary as well as secondary data. A structured questionnaire was set for executing a research survey. This questionnaire is directly connected with different factors and variables collected from secondary research. Here, 5 point Likert type scale is used for measuring the reactions of the employees of construction companies in India. Two stage sampling technique is used in this study. Construction companies and related organizations (Private and Government companies, Tertiary companies, Consulting firms, Contracting firms) in India were chosen through convenience sampling technique in the first stage and sample elements under six different categories with 50 elements each (Civil Engineers, Architects, Builders, Surveyors, Clarks and Others) were chosen randomly from those companies in the second stage. 287 responses out of 300 employees were finally collected for this research. The survey period was from $15^{\text {th }}$ December, 2018 to $15^{\text {th }}$ February, 2019. 


\subsection{Respondents Characteristics}

\begin{tabular}{|c|c|c|c|c|c|c|c|c|c|c|c|}
\hline \multicolumn{1}{|c|}{ Male } & \multicolumn{1}{c|}{ Female } \\
\hline $\begin{array}{c}\text { Engivil } \\
\text { ers }\end{array}$ & $\begin{array}{c}\text { Archite } \\
\text { cts }\end{array}$ & $\begin{array}{c}\text { Build } \\
\text { ers }\end{array}$ & $\begin{array}{c}\text { Survey } \\
\text { ors }\end{array}$ & $\begin{array}{c}\text { Clar } \\
\text { ks }\end{array}$ & $\begin{array}{c}\text { Othe } \\
\text { rs }\end{array}$ & $\begin{array}{c}\text { Civil } \\
\text { Engine } \\
\text { ers }\end{array}$ & $\begin{array}{c}\text { Archite } \\
\text { cts }\end{array}$ & $\begin{array}{c}\text { Build } \\
\text { ers }\end{array}$ & $\begin{array}{c}\text { Survey } \\
\text { ors }\end{array}$ & $\begin{array}{c}\text { Clar } \\
\text { ks }\end{array}$ & $\begin{array}{c}\text { Othe } \\
\text { rs }\end{array}$ \\
\hline 35 & 31 & 26 & 24 & 21 & 37 & 24 & 19 & 18 & 15 & 17 & 20 \\
\hline
\end{tabular}

\section{ANALYSIS AND RESULTS}

For establishing the research model and judging the hypothesis, Structural equation modeling (SEM) by the help of AMOS software has been used in this research. Here, model fitness indexes were tested through structural model. Different factors have been extracted in this study by Exploratory Factor Analysis (EFA) through SPSS which proves the validity of the questionnaire.

Table $1 \mathrm{KMO}$ and Bartlett's Test

\begin{tabular}{|c|c|c|}
\multicolumn{2}{|c|}{$\begin{array}{c}\text { Kaiser-Meyer-Olkin Measure of Sampling } \\
\text { Adequacy. }\end{array}$} & $\mathbf{0 . 7 2 4}$ \\
\hline \multirow{3}{*}{$\begin{array}{c}\text { Bartlett's Test of } \\
\text { Sphericity }\end{array}$} & Approx. Chi-Square & 4537.799 \\
\cline { 2 - 3 } & Df & 153 \\
\cline { 2 - 3 } & Sig. & $<\mathbf{0 . 0 0 1}$ \\
\hline
\end{tabular}

In this study, KMO and Bartlett's Test (Table 1) indicates the aptness of using exploratory factor analysis (EFA).

Table 2 Overall Reliability Statistics

\begin{tabular}{|c|c|}
$\begin{array}{c}\text { Cronbach's } \\
\text { Alpha }\end{array}$ & $\begin{array}{c}\text { No. of } \\
\text { Items }\end{array}$ \\
\hline 0.768 & 18 \\
\hline
\end{tabular}

The overall Cronbach alpha is 0.894 which is greater than 0.70 (Table 2), indicates the suitable range of reliability of collected data. Variables which are associated with 'factor loadings' having more than 0.5 have created 5 factors as mentioned below (Table 3 ) in Rotated Component Matrix. Total $89.541 \%$ of the variations can be explained here by those extracted factors. 
Model Development for Employee Retention in Indian Construction Industry using Structural Equation Modeling (Sem)

Table 3 Result of factor analysis - Rotated Component Matrix

\begin{tabular}{|c|c|c|c|c|c|}
\hline \multirow[b]{2}{*}{ Variables } & \multicolumn{5}{|c|}{ Component } \\
\hline & Basic Facilities & Scope \& Opportunity & $\begin{array}{c}\text { Working } \\
\text { Environment }\end{array}$ & Employee Retention & $\begin{array}{c}\text { Employee } \\
\text { Satisfaction }\end{array}$ \\
\hline $\mathrm{q} 8$ & .954 & .060 & .082 & .098 & .203 \\
\hline q6 & .950 & .071 & .058 & .129 & .208 \\
\hline q5 & .950 & .068 & .089 & .131 & .197 \\
\hline $\mathrm{q} 7$ & .949 & .045 & .093 & .151 & .196 \\
\hline $\mathrm{q} 10$ & .031 & .945 & .021 & .007 & .099 \\
\hline q12 & .060 & .911 & .045 & .020 & .137 \\
\hline q11 & .017 & .900 & .033 & .098 & .040 \\
\hline q9 & .104 & .846 & -.021 & .047 & .091 \\
\hline q1 & .057 & .028 & .911 & .086 & .113 \\
\hline $\mathrm{q} 4$ & .081 & .028 & .905 & .048 & .116 \\
\hline $\mathrm{q} 3$ & .093 & -.022 & .876 & .065 & .127 \\
\hline $\mathrm{q} 2$ & .051 & .039 & .868 & .064 & .007 \\
\hline $\mathrm{q} 18$ & .116 & .138 & .080 & .947 & .151 \\
\hline q16 & .168 & .015 & .093 & .946 & .235 \\
\hline $\mathrm{q} 17$ & .168 & .015 & .093 & .946 & .235 \\
\hline q15 & .263 & .181 & .100 & .199 & .854 \\
\hline $\mathrm{q} 13$ & .319 & .175 & .166 & .267 & .849 \\
\hline $\mathrm{q} 14$ & .303 & .091 & .174 & .286 & .823 \\
\hline $\begin{array}{c}\quad \% \text { of } \\
\text { Variance } \\
\text { Explained }\end{array}$ & 22.152 & 18.663 & 18.284 & 16.538 & 13.904 \\
\hline
\end{tabular}

All indices of Structural model (Table 4) prove the fitness of the research model. Path Analysis was executed for checking the impact of different factors on Employee Satisfaction and Retention in Indian construction companies.

Table 4 Fit indices of Confirmatory Factor Analysis for Structural Model

\begin{tabular}{|c|c|c|}
\hline Fit Index & $\begin{array}{c}\text { Acceptable Threshold } \\
\text { Levels }\end{array}$ & $\begin{array}{c}\text { Structural Model } \\
\text { Values }\end{array}$ \\
\hline$\chi 2 /$ df ( Chi-square / degree of freedom) & Values less than 3 & 0.719 \\
\hline $\begin{array}{c}\text { RMSEA (Root mean-square error of } \\
\text { approximation) }\end{array}$ & Values less than 0.06 & 0.001 \\
\hline GFI (Goodness of fit index) & Values greater than 0.90 & 0.998 \\
\hline AGFI (Adjusted goodness of fit index) & Values greater than 0.90 & 0.985 \\
\hline NFI (Normed fit index) & Values greater than 0.90 & 0.997 \\
\hline CFI (Comparative fit index) & Values greater than 0.90 & 0.999 \\
\hline
\end{tabular}




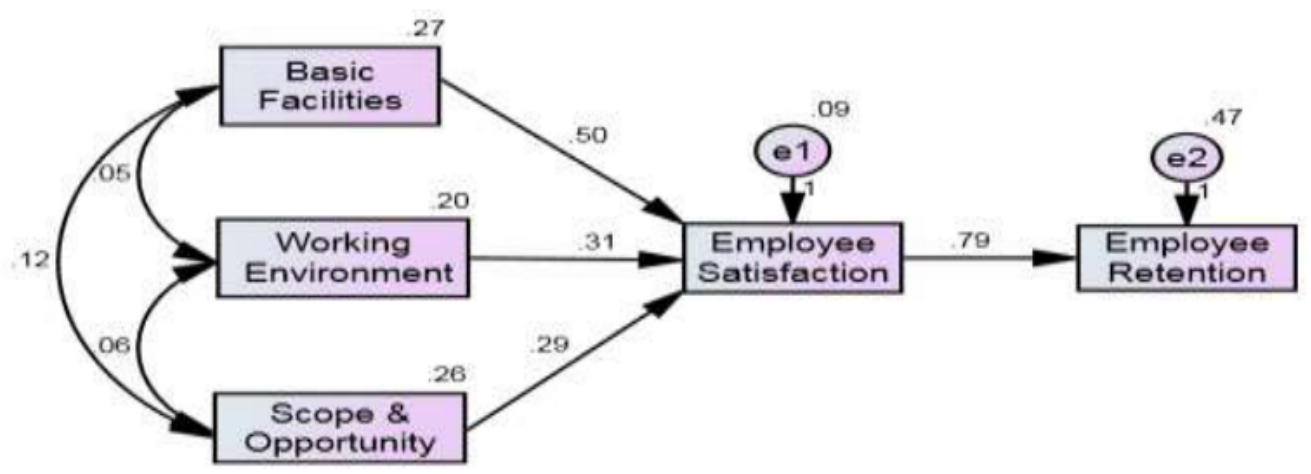

Figure 2 Outcome of hypothesized structural model

Table 5 Path analysis of Structural Model

\begin{tabular}{|c|c|c|c|c|c|c|c|c|}
\hline \multicolumn{2}{|c|}{ Measurement Path } & Hypothesis & Estimate & S.E. & C.R. & $\begin{array}{c}\text { P- } \\
\text { Value }\end{array}$ & Assessment \\
\hline $\begin{array}{c}\text { Employee } \\
\text { Satisfaction }\end{array}$ & $\leftarrow$ & $\begin{array}{c}\text { Basic } \\
\text { Facilities }\end{array}$ & $\mathrm{H} 1$ & .499 & .038 & 13.217 & $.001^{*}$ & Supported \\
\hline $\begin{array}{c}\text { Employee } \\
\text { Satisfaction }\end{array}$ & $\leftarrow$ & $\begin{array}{c}\text { Working } \\
\text { Environment }\end{array}$ & $\mathrm{H} 2$ & .315 & .040 & 7.841 & $.001^{*}$ & Supported \\
\hline $\begin{array}{c}\text { Employee } \\
\text { Satisfaction }\end{array}$ & $\leftarrow$ & $\begin{array}{c}\text { Scope } \\
\text { Opportunity }\end{array}$ & $\mathrm{H} 3$ & .286 & .039 & 7.334 & $.004^{*}$ & Supported \\
\hline $\begin{array}{c}\text { Employee } \\
\text { Retention }\end{array}$ & $\leftarrow$ & $\begin{array}{c}\text { Employee } \\
\text { Satisfaction }\end{array}$ & $\mathrm{H} 4$ & .795 & .080 & 9.920 & $.001^{*}$ & Supported \\
\hline
\end{tabular}

Note: * indicates $1 \%$ level of significance

\subsection{Path Analysis for Hypothesis Testing (Table 5 \& Figure 2)}

H1: 'Basic Facilities' positively influences 'Employee Satisfaction' in Construction Industry.

Structural model supports this hypothesis because of significant path coefficient $(p<0.01)$ and expected positive sign (+.499). Proper salary structure, job security, recognition, etc. can create a positive impact on employee satisfaction. Proper infrastructure makes easier many difficult jobs, if most of the energy and time is wasted due to improper availability of the infrastructure then it is became frustrating situation among employees which leads to develop dissatisfaction (Iyabo, 2013).

H2: 'Working Environment' positively influences 'Employee Satisfaction' in Construction Industry.

Structural model supports this hypothesis because of significant path coefficient $(p<0.01)$ and expected positive sign (+.315). A positive working environment ensures many things such as communication, leadership, workload distribution, motivation from colleagues etc. (Richards, et al., 1994). Employees are always looking for those construction companies where these characteristics are found.

H3: 'Scope \& Opportunity' positively influences 'Employee Satisfaction' in Construction Industry.

Significant $\mathrm{P}$-value $(\mathrm{p}<0.01)$ with positive $(+.286)$ path co-efficient supports the hypothesis. The employees are always seeking for their own career development (Hiltrop, 1999) for that reasons those organizations which are giving full autonomy and recognition to the employee 
Model Development for Employee Retention in Indian Construction Industry using Structural Equation Modeling (Sem)

and have plenty of training \& development opportunity, which is able to gather loyalty among the employees.

H4: 'Employee Satisfaction' positively influences 'Employee Retention' in Construction Industry.

Significant $\mathrm{P}$-value $(\mathrm{p}<0.01)$ with positive $(+.795)$ path co-efficient supports the hypothesis. It should be taken seriously that an efficient employee is having ample amount of job opportunity so if any organization ignores their employee satisfaction, then the organization will never retain their employee.

\section{IMPLICATION OF THE STUDY}

The study helps to understand the factors affecting the employee satisfaction and retention in construction industry in India. The employee retention is directly associated with the employee satisfaction. Any construction company is not able to retain their employees if they ignore some issues i.e. basic facilities, working environment and scopes and opportunities. The study reveals that the employees are more concerned with the basic facilities of the construction company. Basic facilities have higher impact on the employee satisfaction. Working environment and scope \& opportunities have moderate but positive correlation with the employee satisfaction in construction companies in India. The employees are the most important factors to uplift the brand name of the organization because it ensures the continuous improvement of the sector. This research paper helps to understand the key areas which are needed to be improved by construction industry to retain their good employees which in return ensure the organizational development.

\section{CONCLUSION}

Every employee in construction companies is important. If organization is failed to retain their employees then the organization will never be able to sustain in the market place. To sustain and flourish in the market every construction company need to provide identified benefits which are demanded by the employees; also the organizations should engage themselves in continuous improvement process.

\section{Annexure 1}

\begin{tabular}{|c|c|}
\hline Factors & Questions on different Variables \\
\hline \multirow{4}{*}{$\begin{array}{c}\text { Basic } \\
\text { Facilities }\end{array}$} & Good compensation structure helps to satisfy the employees in the organization. \\
\cline { 2 - 3 } & Availability of enough infrastructure helps to satisfy the employees in the organization. \\
\cline { 2 - 3 } Scope \& & Job security helps to satisfy the employees in the organization. \\
\cline { 2 - 3 } Opportunity & Availability of medical facilities helps to satisfy the employees in the organization. \\
\cline { 2 - 3 } & Provision of autonomy in work helps to satisfy the employees in organization. \\
\cline { 2 - 3 } Working & Opportunities of career development help to satisfy the employees in the organization. \\
\cline { 2 - 3 } Environment & Opportunities of training and development help to satisfy the employees in the organization. \\
\cline { 2 - 3 } & A good Communication with colleague, managements, subordinate and other stakeholders \\
& Prelp to satisfy the employees in the organization. \\
\cline { 2 - 3 } & Proper leadership and supervision help to satisfy the employees in the organization. \\
\cline { 2 - 3 } Employee & Motivation from colleagues helps to satisfy the employees in the organization. \\
\cline { 2 - 3 } Satisfaction & Basic facilities help to promote the employee satisfaction. \\
\cline { 2 - 3 } & Working environment helps to promote the employee satisfaction. \\
\cline { 2 - 3 } & Scopes and opportunities help to promote the employee satisfaction. \\
\hline
\end{tabular}


Dr. Arunangshu Giri, Dr. Sourav Gangopadhyay, Jayeeta Majumder and Dr. Pradip Paul

\begin{tabular}{|c|c|}
\hline Factors & Questions on different Variables \\
\hline \multirow{2}{*}{$\begin{array}{c}\text { Employee } \\
\text { Retention }\end{array}$} & Good working environment helps to promote the employee retention. \\
\cline { 2 - 2 } & Career opportunities help to promote the employee retention. \\
\cline { 2 - 2 } & Proper basic facilities help to promote the employee retention. \\
\hline
\end{tabular}

\section{REFERENCES}

[1] Amin, E.K., Ofori, I and Okyere, S, Factors affecting job skills of employees in the construction supply chain in the Ashnati region of Ghana. European Journal of Business and Management, 17 (6), 2015, pp 72-81

[2] Anifowose, M.O. \& Lawal P.O, State of facilities in Nigerian tertiary educational institutions. Journal of Technological Research. 8 (1), 2013, pp 56-60.

[3] Bhatti, K. K., Nawab, S., \& Akbar, A, Effect of direct participation on organizational commitment. International Journal of Business and Social Science, 2(9), 2011, pp 15-23

[4] Blair, R. \& Jordan, J, Staff Loss and Retention at Selected African Universities. A Synthesis Report. Washington, D.C.: The World Bank, 1994

[5] Danso, $\mathrm{H}$, Construction workers satisfaction with work provision requirement dimensions in Ghana Construction Industry, Kumasi, International Journal of Engineering and Technology, 2(9), 2012

[6] Dockel, A, The effect of retention factors on organizational commitment, an investigation of high technology employees. Masters dissertation. University of Pretoria. 2003

[7] George, JM. \& Jones, GR, Essentials of Managing Organizational Behaviour. New Jersey: Prentice-Hall, Inc ,1999

[8] Heish, H.L, Building employees' organisational commitment with LMX: the mediating role of supervisor support. Global Journal of Engineering Education, 14(3), 2012, pp 250-255.

[9] Hiltrop, JM, The quest for the best: Human resource practices to attract and retain talent. Europe Manage Journal, 17(4), 1999, pp 422-430

[10] Huselid, M.A, The impact of human resource management practices on turnover, productivity, and corporate financial performance. Academy of Management Journal, 38(3), 1995, pp 635-672.

[11] IFMA, Operation and maintenance benchmarks. Research Report, International Facility Management Association, 2001

[12] Iyabo, O. M. B, Sources of Workplace Stressors among University Lecturers in South West Nigeria: Implication for Counselling. 1st Annual International Interdisciplinary Conference Proceedings, 2013, pp. 24-26.

[13] Kasule, G. W, Impact of Work Environment on Academic Staff Job Performance: Case of a Uganda University. International Journal of Advances in Management and Economics, 4 (4), 2015, pp 95-103.

[14] Landsman, M.J. (2008). Pathways to organizational commitment. Administration in Social Work, 32(2), 2008, pp 105-132.

[15] Metcalf, H.; Rolfe, H.; Stevens, P. \& Amar. A.D, Motivating knowledge workers to innovate: A model integrating motivation dynamics and antecedents. European Journal of Innovation Management, 7(2), 2005, pp 89-101.

[16] Miller, N.G.; Erickson, A. \& Yust, B.L, Sense of place in the workplace: The relationship between personal objects and job satisfaction and motivation. Journal of Interior Design, 27(1), 2001, pp 35-44.

[17] Mubatsi, A.H, Uganda: Makerere Losing Staff over Low Pay. The Independent. Kampala: Uganda, 2012

[18] Dr. R. Srinivasan, R. Divyaranjani and Dr. S. Poongavanam, A Analysis on Employee Relation and Psychological Wok Commitment in Production and Manufacturing Insustries 
Model Development for Employee Retention in Indian Construction Industry using Structural Equation Modeling (Sem)

in India, International Journal of Mechanical Engineering and Technology 9(7), 2018, pp. 1197-1208.

[19] Ng'ethe, J.M.; Iravo, M.E. \& Namusonge, G.S, Determinants of academic staff retention in public Universities in Kenya: Empirical review. International Journal of Humanities and Social Science, 2(13), 2012, pp 205-212.

[20] Ngonde, D.F, Job satisfaction among workers in the construction industry: a case of national Housing Corporation. MSc Thesis, Open University of Tanzania. Of Statistical Modelling and Analytics. 1(2), 2015, pp 45-59.

[21] Ojelabi, Rapheal A., Afolabi, A.O., Oyeyipo, O., Tunji-Olayeni, P .F and Adewale B.A, Data exploration of social client relationship management (CRM 2.0) adoption in the Nigerian construction business. Data in Brief, 18. 1471-1476, 2018

[22] Richards, B.; O'Brien, T. \& Akroyd, D, Predicting the organizational commitment of marketing education and health occupations education teachers by work related rewards. Journal of Industrial Teacher Education, 32(1), 1994, pp 49-64.

[23] Strauss, G, Worker participation - some under considered issues. Industrial Relations, 45, 2006, pp 778-803.

[24] Khalid Imran and Dr. K.V.A. Balaji, a Comparative Survey of the Impact of Training and Development on Quality of Work Life of Employees Working in Private and Public Manufacturing Industries, International Journal of Mechanical Engineering and Technology (Ijmet), Volume 5, Issue 9, September (2014), pp. 126-132

[25] Zainudin, A., Junaidah, H.A. \& Nazmi, M.Z, Modelling job satisfaction and work commitment among lecturers: A case of UITM Kelantan. Journal of Statistical Modelling and Analytics, 1(2), 2010, pp 45-59.

[26] Dr. D. Rajasekar, Dr. A. Krishna Sudheer and Dr. P. Raghunadha Reddy, A Study on Employee Empowerment in Indian Corporate Sector. International Journal of Civil Engineering and Technology, 8(11), 2017, pp. 268-277.

[27] Ruchika Malik, Tanavi Madappa, Dr. Ravinder Kaur, Dr. Jaya Chitranshi, A Conceptual Study on the Impact of Role Efficacy on the Motivation Levels of Employees. International Journal of Marketing and Human Resource Management, 7(3), 2016, pp. 10-17. 